\begin{tabular}{|l|l|l||}
\hline \multicolumn{2}{|c|}{ PublisherInfo } \\
\hline \hline PublisherName & $:$ & BioMed Central \\
\hline \hline PublisherLocation & $:$ & London \\
\hline \hline PublisherImprintName & $:$ & BioMed Central \\
\hline \hline
\end{tabular}

\title{
Miniature Genome
}

\begin{tabular}{|l|l|l||}
\hline \multicolumn{2}{|c|}{ ArticleInfo } \\
\hline \hline ArticleID & $:$ & 4367 \\
\hline \hline ArticleDOI & $:$ & $10.1186 /$ gb-spotlight-20020102-01 \\
\hline \hline ArticleCitationID & $:$ & spotlight-20020102-01 \\
\hline \hline ArticleSequenceNumber & $:$ & 33 \\
\hline \hline ArticleCategory & $:$ & Research news \\
\hline \hline ArticleFirstPage & $:$ & 1 \\
\hline \hline ArticleLastPage & $:$ & 2 \\
\hline \hline & & RegistrationDate : 2002-01-02 \\
ArticleHistory & $:$ & OnlineDate \\
\hline \hline ArticleCopyright & $:$ & BioMed Central Ltd2002-01-02 \\
\hline \hline ArticleGrants & $:$ & \\
\hline \hline ArticleContext & $:$ & 130593311 \\
\hline \hline
\end{tabular}




\section{Jonathan B Weitzman}

Email: jonathanweitzman@hotmail.com

The 'Year of the Genome' ends with the publication of a tiny genome, that of the marine chordate Oikopleura dioica. Oikopleura is a small pelagic chordate that measures just $5 \mathrm{~mm}$. It is easy to culture and has a short life cycle (2-4 days) and high female fecundity (around 300 oocytes). In the December 21 Science, Seo et al. report the genome sequence of $O$. dioica (Science 2001, 294:2506). They used large-scale shotgun sequencing to assemble contigs covering $32.6 \mathrm{Mb}$. The total genome is estimated to be $65 \mathrm{Mb}$, making it the smallest chordate genome known. They estimate that the genome contains some 15,000 genes, at a density of one gene every $5 \mathrm{~kb}$; introns and intergenic regions were very short. The compact nature of this genome may make it an interesting model for future genomic studies.

\section{References}

1. Oikopleura dioica: larvacean, [http://jellieszone.com/oikopleura.htm]

2. Science, [http://www.sciencemag.org] 